\title{
DAMPAK IKLIM ORGANISASI TERHADAP STRES KERJA DAN KINERJA KARYAWAN
}

\author{
Muhammad Rasyid Abdillah, Rizqa Anita dan Rita Anugerah \\ Jurusan Manajemen Sekolah Tinggi Ilmu Ekonomi Purna Graha \\ dan Fakultas Ekonomi Universitas Riau \\ email: sheedabdillah@gmail.com
}

\begin{abstract}
This study aims to examine the impact of organizational climate on job stress and employee performance. The data used in this study was primary data in the form of a questionnaire in which the research subjects are 45 employees of PT. Adei Plantation \& Industry Head Office Pekanbaru Riau. To test the hypothesis using Structural Equation Modeling Partial Least Square. The result suggest that organizational climate influence on job stress and employee performance. In addition, result also suggest that the effect of organizational climate on employee performance is indirect influence through job stress.
\end{abstract}

Keywords: Organizational climate, job stress, employee performance

\begin{abstract}
Abstrak: Penelitian ini bertujuan untuk menguji dampak iklim organisasi terhadap stres kerja dan kinerja karyawan. Data yang digunakan dalam penelitian ini adalah data primer dalam bentuk kuesioner dimana subjek penelitiannya adalah para 45 karyawan PT. Adei Plantation \& Industry Head Office Pekanbaru Riau. Pengujian hipotesis menggunakan Structural Equation Modeling Partial Least Square. Hasil penelitian menunjukkan bahwa iklim organisasi berpengaruh terhadap stres kerja dan kinerja karyawan. Selain itu, hasil ini juga menunjukkan bahwa pengaruh iklim organisasi terhadap kinerja karyawan adalah pengaruh tidak langsung melalui stres kerja.
\end{abstract}

Keywords: Iklim organisasi, stres kerja, kinerja karyawan

\section{PENDAHULUAN}

Kinerja merupakan tujuan akhir di setiap usaha yang dilakukan baik secara individu, kelompok, maupun organisasi (Suandi et al., 2014). Kinerja karyawan secara langsung berhubungan dengan produktivitas dan keberhasilan perusahaan dalam mencapai tujuannya (Shahzad et al., 2011; Fitriastuti, 2013). Kinerja karyawan adalah hasil atau dampak dari kegiatan individu selama periode waktu tertentu (Shahzad et al., 2011). Mengelola kinerja karyawan sangat diperlukan untuk mencapai tujuan organisasi yang telah ditetapkan. Agar mampu mengelola kinerja karyawan, pihak manajemen perusahaan perlu mengetahui dan memahami faktor-faktor yang mempengaruhi kinerja karyawan karena dengan memahami hal tersebut, manajemen dengan mudah mencari solusi dan keputusan yang efektif berkaitan dengan kinerja karyawan (Fitriastuti, 2013).

Saat ini, kinerja karyawan dalam beberapa perusahaan masih menjadi permasalahan yang selalu dihadapi oleh pihak manajemen (Fitriastuti, 2013) termasuk PT Adei Plantation \& Industry Head Office Pekanbaru Riau yang merupakan Group perusahaan Kuala Lumpur Kepong Berhad Malaysia. Masalah kinerja karyawan pada perusahaan ini dapat dilihat dalam aktivitas kerja sehari-hari seperti masih terdapat beberapa karyawan 
yang datang ke kantor tidak tepat waktu, pulang kantor sebelum waktunya, sering keluar masuk kantor pada saat jam kerja, dan tidak mampu menyelesaikan tugas pekerjaan yang dibebankan kepadanya sesuai dengan waktu yang ditentukan. Hal ini mengindikasikan bahwa masih terdapat beberapa karyawan yang memiliki kualitas kinerja yang rendah.

Penelitian-penelitian mengenai faktor yang mempengaruhi kinerja selalu dilakukan oleh peneliti di bidang manajemen khususnya manajemen sumber daya manusia dan perilaku organisasi. Diantaranya adalah penelitian yang dilakukan oleh Adeyemi (2008), Selamat et al. (2013), Suliman dan Harethi (2013), Suandi et al. (2014), dan He et al. (2015) yang menemukan bahwa tinggi rendahnya kinerja karyawan dipengaruhi secara langsung oleh sehat atau tidaknya iklim organisasi yang ada pada perusahaan. Iklim organisasi memainkan peran langsung dalam meningkatkan perilaku dan kinerja individu (He et al., 2015). Hal ini menjelaskan bahwa hasil kerja baik secara kualitas maupun kuantitas yang dicapai seorang karyawan dalam melaksanakan pekerjaan sesuai dengan tanggung jawab yang diberikan perusahaan kepadanya (Mangkunegara, 2010) disebabkan oleh persepsi karyawan tentang karakteristik organisasi yang tercermin dalam kebijakan, praktik dan kondisi yang ada di lingkungan kerja (Schanke, 1983).

Selanjutnya, penelitian Bashir dan Ramay (2010), Cholilawati (2010), Jehangir et al. (2011), Leung et al. (2011), Abdillah (2013), Suandi et al. (2014), Rangriz dan Pashootanizadeh (2014) serta Goswami (2015) menunjukkan bahwa tinggi rendahnya kinerja karyawan disebabkan oleh tinggi atau rendahnya stres kerja yang dialami oleh karyawan. Karyawan yang menderita stres kerja yang tinggi akan mencoba untuk menarik dirinya dari penyebab stres (stressor) dengan cara menciptakan masalah bagi perusahaan seperti ketidakefisienan dalam kinerja, pemborosan sumber daya operasional, menjadi penyebab kendala kerja bagi karyawan lainnya dan lain sebagainya (Goswami, 2015). Hal ini menjelaskan bahwa stres kerja yang tinggi akan memberikan dampak yang buruk pada kinerja karyawan (Mohsan et al., 2011).

Salah satu penyebab munculnya stres kerja yang tinggi adalah iklim organisasi yang tidak sehat (Robbins, 2007; Wagner dan Hollenbeck, 2010; Luthans, 2011; Gibson et al., 2012). Bekerja dalam iklim organisasi tertutup dan tidak sehat membawa emosi negatif dan perasaan oleh karyawan, hal ini termasuk ketidakpuasan, tekanan psikologis, melalaikan, ketidakpedulian, dan akhirnya akan menyebabkan karyawan menghindari pekerjaan yang mengarah ke stres kerja (Ahghar, 2008). Hasil penelitian terakhir menemukan bahwa iklim organisasi memiliki pengaruh terhadap stres kerja (Ahghar, 2008; Putra et. al., 2014; Sert et al., 2014). Aghar (2008) dan Sert et al. (2014) lebih lanjut menemukan bahwa iklim organisasi berpengaruh negatif terhadap stres kerja karyawan. Hal ini mengindikasikan bahwa semakin sehat iklim suatu organisasi maka semakin rendah tingkat stres kerja karyawan. Sebaliknya, semakin tidak sehat iklim suatu organisasi, maka semakin tinggi tingkat stres kerja karyawan.

Beberapa penelitian yang berkaitan dengan faktor-faktor yang mempengaruhi kinerja masih memiliki hasil yang berbeda (tidak konsisten). Kusmaningtyas dan Priyana (2012) dalam penelitiannya menemukan bahwa iklim organisasi tidak berpengaruh terhadap kinerja karyawan. Hasil penelitian ini menjelaskan bahwa hasil kerja yang baik seperti kualitas, kuantitas, pengetahuan, kreativitas, dan inisiatif yang dicapai seseorang dalam menjalankan tugasnya sehari-hari sesuai dengan wewenang dan tanggung jawabnya masing-masing secara langsung tidak dipengaruhi oleh kualitas lingkungan internal organisasi yang secara relatif terus berlangsung, dialami oleh anggota organisasi, memengaruhi perilaku mereka dan dapat dilukiskan dalam pengertian satu set karakteristik 
atau sifat organisasi seperti struktur, tanggung jawab, standar-standar, penghargaan, dukungan, dan komitmen.

Zalukhu (2013); Mangkunegara dan Puspitasari (2015) menemukan bahwa stres kerja tidak mempengaruhi kinerja karyawan. Hasil penelitian ini menjelaskan bahwa prestasi kerja karyawan secara kualitas dan kuantitas dalam melaksanakan tugasnya tidak dipengaruhi oleh perasaan yang dialami karyawan yang diakibatkan oleh situasi, tindakan, atau peristiwa yang menekan yang berasal dari faktor lingkungan, organisasi dan individu dalam menghadapi tugas dan tanggung jawabnya di dalam pekerjaan dan berakibat pada fisilogis, psikologis dan perilaku.

Selanjutnya, Aizzat et al. (2006); Sharma (2013) menemukan bahwa iklim organisasi tidak berpengaruh terhadap stres kerja. Hasil penelitian ini menjelaskan bahwa kesadaran atau perasaan disfungsional dari karyawan sebagai akibat dari kondisi yang dirasakan di tempat kerja dan rekasi psikologis dan fisiologis seorang karyawan terhadap kondisi yang tidak nyaman atau tidak diinginkan tidak dipengaruhi oleh kualitas lingkungan internal organisasi yang secara relatif terus berlangsung, dialami oleh anggota organisasi, memengaruhi perilaku mereka dan dapat dilukiskan dalam pengertian satu set karakteristik atau sifat organisasi seperti struktur, tanggung jawab, standar-standar, penghargaan, dukungan, dan komitmen. Melihat masih adanya hasil penelitian yang berbeda, sehingga, penelitian lebih lanjut mengenai dampak iklim organisasi terhadap stres kerja dan kinerja masih perlu untuk dilakukan.

Sebagian besar penelitian terkait dengan dampak iklim organisasi terhadap stres kerja dan kinerja masih dilakukan secara terpisah (sendiri-sendiri), sehingga tidak dapat memberikan gambaran menyeluruh tentang dampak dari iklim organisasi terhadap stres kerja dan kinerja karyawan. Berbeda dengan beberapa penelitian sebelumnya, penelitian ini bertujuan untuk membuktikan apakah iklim organisasi yang sehat akan memberikan dampak langsung terhadap stres kerja yang rendah dan kinerja karyawan yang tinggi. Penelitian ini lebih lanjut ingin membuktikan apakah kondisi stres kerja yang rendah mampu menjadi mediasi dalam pengaruh tidak langsung antara iklim organisasi yang sehat terhadap kinerja karyawan yang tinggi khususnya pada PT. Adei Plantation \& Industry Head Office Pekanbaru Riau.

Hasil penelitian ini diharapkan dapat memberikan kontribusi bagi PT. Adei Plantation \& Industry Head Office Pekanbaru Riau (kontribusi praktik) serta pengembangan ilmu perilaku organisasi dan manajemen sumber daya manusia (kontribusi teori), terutama yang berkaitan dengan iklim organisasi, stres kerja dan kinerja karyawan. Selanjutnya, hasil penelitian ini juga dapat memberi masukan untuk memahami lebih jauh mengenai peran mediasi stres kerja dalam pengaruh iklim organisasi terhadap kinerja karyawan.

\section{KAJIAN TEORI}

Iklim Organisasi. Istilah iklim organisasi (organizational climate) pertama kali diperkenalkan oleh Lewin et al. (1939) dengan menggunakan istilah iklim sosial (social climate). Iklim merupakan suatu kondisi yang berhubungan dengan pikiran, perasaan, dan perilaku dari anggota organisasi. Oleh karena itu, iklim adalah sebuah penilaian subjektif dan terikat oleh manipulasi penuh dari seseorang dengan kekuasaan dan pengaruhnya (Denison, 1996). Schanke (1983) mendefenisikan iklim organisasi sebagai karakteristik organisasi yang tercermin dalam deskripsi karyawan tentang kebijakan, praktik dan 
kondisi yang ada di lingkungan kerja. Secara lebih luas iklim organisasi didefenisikan oleh Wirawan (2008) sebagai persepsi anggota organisasi (secara individual dan kelompok) dan mereka yang secara tetap berhubungan dengan organisasi (misalnya pemasok, konsumen, konsultan dan kontraktor) mengenai apa yang ada atau terjadi di lingkungan internal organisasi secara rutin, yang mempengaruhi sikap dan perilaku serta kinerja anggota organisasi yang kemudian menentukan kinerja organisasi.

Sejumlah peneliti menaruh perhatian khusus untuk membedakan antara iklim dan budaya organisasi. Orang awam tidak dapat membedakan pengertian konsep iklim dengan budaya organisasi. Sebagai suatu konsep, iklim organisasi mempunyai pengertian yang berbeda dengan budaya organisasi, meskipun keduanya saling berhubungan. Berikut penjelasannya (Wirawan, 2008). Pertama, struktur budaya organisasi berakar pada nilainilai, norma, kepercayaan dan asumsi organisasi. Sedangkan, iklim organisasi melukiskan lingkungan internal organisasi dan berakar pada budaya organisasi. Kedua, jika budaya organisasi relatif bersifat tetap dalam jangka panjang, maka iklim organisasi bersifat relatif sementara dan dapat berubah dengan cepat. Ketiga, iklim organisasi umumnya dapat dengan mudah dikontrol oleh pemimpin dan manajer. Sedangkan, mengembangkan dan merubah budaya organisasi memerlukan upaya yang sistematis, sumber daya besar dan waktu yang lama (Denison, 1996; dan Wirawan, 2008).

Iklim organisasi merupakan persepsi anggota organisasi terhadap dimensi-dimensi iklim organisasi (Wirawan, 2008). Schanke (1983) membagi iklim organisasi menjadi lima dimensi. Pertama, participation and rewards yaitu dimensi yang terdiri dari item yang berhubungan dengan tingkat partisipasi diperbolehkan dalam menetapkan tujuan dan standar kinerja, juga item yang berkaitan dengan hubungan antara kinerja yang dirasakan dan manfaat. Kedua, structure yaitu dimensi yang terdiri dari item yang berkaitan dengan kejelasan kebijakan dan prosedur organisasi, dan kejelasan tujuan dan tugas-tugas. Ketiga, warmth and support yaitu dimensi yang terdiri dari item yang berkaitan dengan hubungan interpersonal antara bawahan dan orang lain dalam organisasi termasuk manajemen. Keempat, standards yaitu dimensi yang berkaitan dengan standar kinerja, kesulitan tujuan, dan tekanan untuk kinerja. Dan yang terakhir, responsibility yaitu dimensi yang mengacu pada tanggung jawab individu dan otonomi.

Stres Kerja. Stres adalah sebuah keadaan emosi negatif yang terjadi dalam menanggapi peristiwa yang dianggap berat atau melebihi sumber daya seseorang atau kemampuan untuk mengatasinya (Hockenbury dan Hockenbury, 2010). Lebih lanjut, Gibson et al. (2012) mendefenisikan stres sebagai suatu respons adaptif yang dimediasi oleh perbedaanperbedaan individu dan atau proses-proses psikologis akibat dari setiap kegiatan, situasi, atau peristiwa yang membebankan tuntutan psikologis dan atau fisik berlebihan pada seseorang.

Stres telah menjadi bagian utama dalam kehidupan manusia modern. Hal ini terusmenerus menimbulkan ancaman dan tantangan untuk kesehatan dan kesejahteraan seseorang. Dengan keadaan saat ini yang tidak pasti, tekanan, frustrasi, tuntutan dan kegagalan yang dirasakan secara terus-menerus di tempat kerja membuat stres tidak bisa dihindari (Estrella, 2014). Stres kerja adalah persepsi perbedaan antara tuntutan lingkungan (stressor) dan kapasitas individu untuk mengisi tuntutan tersebut. Interaksi antara individu dan lingkungan tersebut berakibat mempengaruhi kondisi mental dan fisik individu. Hal ini dapat didefinisikan sebagai berkurangnya fisik dan mental karyawan yang disebabkan oleh bahaya yang dirasakannya (Goswami, 2015). 
Stres kerja adalah salah satu masalah besar di dunia global. Sebagian besar karyawan sering atau sangat sering merasa stres karena pekerjaan (Jehangir et al., 2011). Sobirin (2012) menjelaskan bahwa tidak ada perbedaan esensial antara defenisi stres secara generik maupun yang dikaitkan dengan organisasi atau dunia kerja. Oleh sebab itu, untuk memahami stres kerja ada beberapa hal yang harus dipahami. Pertama, stres bermula dari tekanan lingkungan eksternal yang berlebihan terhadap diri seseorang. Kedua, meski secara normatif stressor menjadi penyebab stres, bukan berarti setiap orang akan mengalami stres manakala berhadapan dengan tekanan lingkungan yang sama. Ketiga, perbedaan respon tersebut lebih disebabkan karena perbedaan latar belakang masingmasing individu. Kemudian yang terakhir, pertanda bahwa stressor menyebabkan seseorang mengalami stres dapat dilihat dari ketidakseimbangan atau guncangan psikologis, fisiologis dan atau perilaku seseorang.

Stres kerja juga dilihat sebagai dysfunctional bagi organisasi dan anggotanya (Bashir dan Ramay, 2010) karena sebagian besar karyawan yang menderita stres kerja selalu menunjukkan gejala-gejala yang dapat merugikan baik bagi karyawan sebagai individu maupun perusahaan tempat ia bekerja (Mohsan et al., 2011). Karyawan yang menderita stres kerja dapat dilihat dari gejala-gejala seperti (Robbins, 2007) : (a) selalu mengalami gangguan pencernaan akibat bekerja, selalu merasakan sakit kepala karena beban pekerjaan (gejala fisiologis); (b) merasa putus asa, mudah tersinggung, gelisah dalam bekerja, sulit untuk berkosentrasi, kurang bersemangat dalam bekerja (gejala psikologis); (c) sering tidak masuk kerja, sulit tidur karena memikirkan pekerjaan, dan nafsu makan berkurang atau berlebihan secara tidak wajar (gejala perilaku).

Rivai dan Mulyadi (2009) menjelaskan bahwa terdapat lima faktor yang dapat menimbulkan stres kerja yaitu (a) faktor-faktor instrinsik dalam pekerjaan seperti tuntuan fisik dan tuntutan tugas; (b) peran individu dalam organisasi; (c) pengembangan karir; (d) hubungan interpersonal dalam pekerjaan; (e) struktur dan iklim organisasi. Lebih lanjut, Luthans (2011) menjelaskan bahwa sumber atau penyebab stres terdiri atas empat hal utama yaitu (a) extra organizational stressor yaitu penyebab stres yang bersumber dari luar organisasi; (b) organizational stressor yaitu penyebab stres yang berasal dari dalam organisasi; (c) group stressor yaitu penyebab stres yang berasal dari kelompok; (d) individual stressor yaitu penyebab stres yang berasal dari individu karyawan.

Kinerja Karyawan. Kinerja merupakan hasil dari suatu tindakan yang memberikan kontribusi bagi keberhasilan organisasi dalam mencapai tujuannya (Suandi et al., 2014). Sementara itu, Kinerja karyawan adalah hasil atau dampak dari kegiatan individu selama periode waktu tertentu (Shahzad et al., 2011). Rajan (2015) memberikan defenisi tentang kinerja sebagai suatu kegiatan di mana seorang individu mampu dan berhasil menyelesaikan tugas yang diberikan kepadanya, patuh pada aturan atau prosedur dalam pemanfaatan sumber daya yang telah tersedia. Lebih lanjut, Mangkunegara (2010) mendefenisikan kinerja karyawan sebagai hasil kerja secara kualitas maupun kuantitas yang dicapai seorang karyawan dalam melaksanakan tugasnya sesuai dengan tanggung jawab yang diberikan perusahaan kepadanya.

Mengelola kinerja karyawan sangat diperlukan untuk mencapai tujuan organisasi yang telah ditetapkan. Menilai kompetensi karyawan dan mengukur produktivitasnya sangat penting dalam rencana keseluruhan organisasi (Shahzad et al., 2011). Dalam perusahaan yang baik, pada umumnya kinerja karyawan dikelola dengan menggunakan proses formal yaitu penilaian dari supervisor, management by objective, penilaian 360- 
derajat, dan penilaian dari rekan kerja atau tim, dan lain sebagainya (Mondy, 2008) untuk memastikan bahwa karyawan telah memberikan kontribusi terhadap pengembangan diri mereka dan perusahaan (Shahzad et. al., 2011).

Melakukan penilaian terhadap kinerja karyawan merupakan hal yang sangat penting dalam manajemen sumber daya manusia. Apabila penilaian tersebut dilaksanakan dengan baik maka akan memberikan dampak yang sangat penting bagi karyawan, manajer, maupun perusahaan (Suandi et. al., 2014). Penilaian kinerja karyawan dalam perusahaan harus dilakukan agar dapat mengetahui keputusan apa yang akan diambil oleh perusahaan untuk peningkatan gaji, pelatihan dan pengambangan, perencanaan karir, promosi dan penempatan karyawan (Abdillah, 2013).

Pengaruh Langsung Terhadap kinerja. Iklim Organisasi dan Kinerja. Berkaitan dengan kondisi organisasi yang terus berubah, penting untuk mengelola iklim yang baik atau kondusif dalam menunjang aktivitas kerja karyawan (Putra et al., 2014). Iklim organisasi memainkan peran langsung dalam meningkatkan perilaku dan kinerja individu (He et al., 2015). Iklim organisasi yang kondusif dan produktif sangat penting untuk memperkuat dan mempertahankan ikatan antara organisasi dan karyawan karena mampu menjaga dan melestarikan motivasi dan kinerja yang tinggi (Miller, 2002; Suliman dan Harethi, 2013). Suatu iklim organisasi yang diterima oleh karyawan adalah salah satu faktor paling penting yang mempengaruhi dan berdampak pada persepsi karyawan mengenai kontribusi dan keterlibatan di tempat kerja (Shadur et al., 1999). Karyawan yang dihadapkan pada sebuah iklim kerja yang telah melakukan information sharing, dukungan manajemen yang positif, kontribusi dan keterlibatan dalam proses pengambilan keputusan cenderung akan memberikan dampak yang positif terhadap pekerjaan. Karyawan yang memahami dan merasakan lingkungan kerja yang memadai, aman dan menyenangkan akan mengembangkan sikap positif terhadap berbagai komponen pekerjaan yang pada akhirnya menghasilkan keterlibatan kerja dan kinerja yang lebih tinggi (Suliman dan Harethi, 2013).

Beberapa penelitian terakhir menemukan bahwa iklim organisasi memiliki pengaruh yang positif dan signifikan terhadap kinerja karyawan (Adeyemi, 2008; Selamat et al., 2013; Suliman dan Harethi, 2013; Suandi et al., 2014; He et al., 2015). Hal ini mengindikasikan bahwa semakin kondusif (sehat) iklim suatu organisasi, maka semakin tinggi pula tingkat kinerja individu karyawan. Sebaliknya, semakin tidak kondusif (tidak sehat) iklim suatu organisasi, maka semakin rendah tingkat kinerja individu karyawan. Berdasarkan uraian tersebut maka dirumuskan hipotesis sebagai berikut :

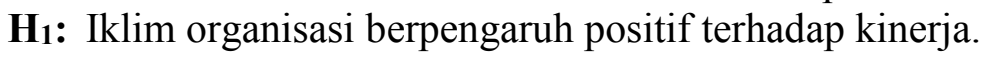

Stres Kerja dan Kinerja. Stres di tempat kerja memiliki pengaruh yang signifikan terhadap kinerja karyawan (Bashir dan Ramay, 2010). Lebih lanjut, Mohsan et al. (2011) menjelaskan bahwa kekhawatiran yang paling penting dalam studi stres kerja adalah dampak buruk pada kinerja karyawan. Karyawan yang menderita stres akan mencoba untuk menarik dirinya dari penyebab stres (stressor) dengan cara keluar dari perusahaan dan atau tidak hadir dalam pekerjaan. Apabila keluar dari perusahaan merupakan sesuatu yang sulit bagi karyawan, maka mereka akan menciptakan masalah bagi perusahaan seperti ketidakefisienan dalam kinerja, pemborosan sumber daya operasional, menjadi penyebab kendala kerja bagi karyawan lainnya dan lain sebagainya (Goswami, 2015). Beberapa studi terakhir menemukan bahwa stres kerja berpengaruh negatif terhadap kinerja karyawan (Bashir dan Ramay, 2010; Cholilawati, 2010; Jehangir et al., 2011; 
Leung et al., 2011; Abdillah, 2013; Suandi et al., 2014; Rangriz dan Pashootanizadeh, 2014; Goswami, 2015). Hal ini menunjukkan bahwa karyawan yang memiliki stres kerja yang tinggi akan cenderung memiliki kinerja yang rendah. Sebaliknya, karyawan dengan stres kerja yang rendah akan cenderung memiliki kinerja yang tinggi. Berdasarkan uraian tersebut maka dirumuskan hipotesis sebagai berikut :

$\mathbf{H}_{2}$ : Stres kerja berpengaruh negatif terhadap kinerja.

Pengaruh Tidak Langsung Terhadap kinerja. Iklim Organisasi dan Stres Kerja. Iklim organisasi merupakan salah satu faktor penyebab munculnya stres kerja karyawan yang berasal dari dalam organisasi (Robbins, 2007; Wagner dan Hollenbeck, 2010; Luthans, 2011; Gibson et al., 2012). Bekerja dalam iklim organisasi tertutup dan tidak sehat membawa emosi dan perasaan negatif bagi karyawan. Hal ini akan menimbulkan ketidakpuasan, tekanan psikologis, melalaikan, ketidakpedulian, dan akhirnya akan menyebabkan karyawan menghindari pekerjaan yang mengarah ke stres kerja (Ahghar, 2008). Hasil penelitian terakhir menemukan bahwa iklim organisasi memiliki pengaruh terhadap stres kerja (Ahghar, 2008; Putra et. al., 2014; Sert et al., 2014). Aghar (2008) dan Sert et al. (2014) selanjutnya menemukan bahwa iklim organisasi berpengaruh negatif terhadap stres kerja karyawan. Hal ini mengindikasikan bahwa semakin sehat iklim suatu organisasi maka semakin rendah tingkat stres kerja karyawan. Sebaliknya, semakin tidak sehat iklim suatu organisasi, maka semakin tinggi tingkat stres kerja karyawan. Berdasarkan uraian tersebut maka dirumuskan hipotesis sebagai berikut:

$\mathbf{H}_{1 \mathbf{a}}$ : Iklim organisasi berpengaruh negatif terhadap stres kerja.

Peran Mediasi Stres Kerja Pada Iklim Organisasi dan Kinerja. Seperti yang telah dijelaskan sebelumnya, bahwa kekhawatiran yang paling penting dalam studi stres kerja adalah dampak buruk pada kinerja karyawan (Mohsan et al., 2011). Situasi stres di tempat kerja yang bertahan lama membuat dampak negatif tidak hanya pada kinerja karyawan tetapi juga menghambat kinerja keseluruhan pada tingkat organisasi (Goswami, 2015). Sementara itu, salah satu penyebab tingginya tingkat stres kerja adalah iklim organisasi yang tidak sehat (Ahghar, 2008; Putra et. al., 2014; Sert et al., 2014). Persepsi karyawan tentang karakteristik organisasi yang tercermin dalam kebijakan, praktik dan kondisi yang ada di lingkungan kerja yang tidak sehat akan menimbulkan emosi negatif yang pada akhirnya akan menyebabkan stres kerja yang dirasakan oleh karyawan (Schanke, 1983; Ahghar, 2008). Selanjutnya, karyawan yang menderita stres akan mencoba untuk menarik dirinya dari penyebab stres (stressor) dengan cara keluar dari perusahaan dan atau tidak hadir dalam pekerjaan. Apabila keluar dari perusahaan merupakan sesuatu yang sulit bagi karyawan, maka mereka akan menciptakan masalah bagi perusahaan seperti ketidakefisienan dalam kinerja, pemborosan sumber daya operasional, menjadi penyebab kendala kerja bagi karyawan lainnya dan lain sebagainya (Goswami, 2015). Berdasarkan uraian tersebut maka dirumuskan hipotesis sebagai berikut :

$\mathbf{H}_{1 \mathbf{b}}$ : Iklim organisasi berpengaruh tidak langsung terhadap kinerja karyawan melalui stres kerja. 


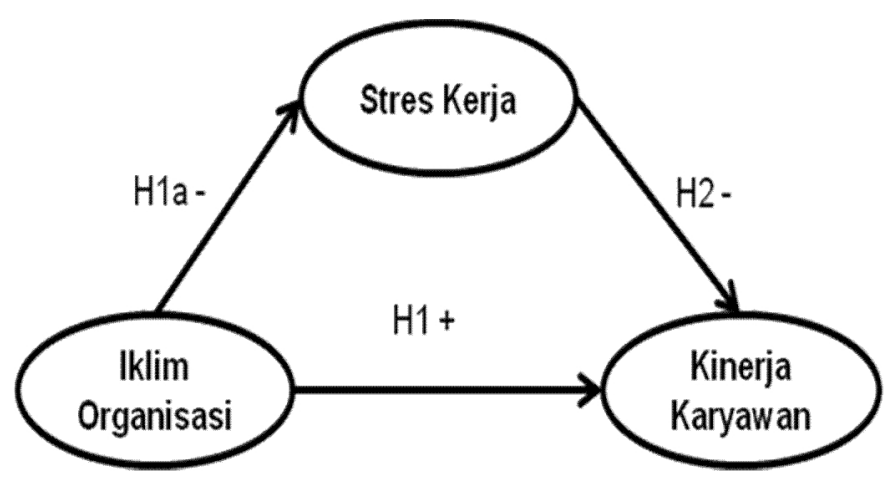

\section{METODE}

Gambar 1. Model Penelitian

Sampel dan Data Penelitian. Sumber data dalam penelitian ini berasal dari data primer yang diperoleh dari jawaban responden atas kuesioner yang diberikan kepada karyawan PT. Adei Plantation \& Industry Head Office Pekanbaru Riau yang berjumlah 60 karyawan. Penyebaran kuesioner dilakukan dengan cara mendatangi perusahaan secara langsung. Jumlah kuesioner yang disebar sebanyak 60 kuesioner. Jumlah keseluruhan kuesioner yang diisi dan kembali sebanyak 50 kuesioner dengan tingkat pengembalian 83,3 persen. Sedangkan jumlah kuesioner yang tidak kembali sebanyak sepuluh eksemplar kuesioner. Setelah melakukan penyeleksian atas jawaban responden ternyata lima kuesioner tidak dapat digunakan dalam analisis data karena tidak diisi dengan lengkap. Dengan demikian jumlah sampel penelitian ini yang bisa digunakan adalah 45 eksemplar kuesioner dengan tingkat pengembalian efektif sebanyak 75,0 persen.

Operasionalisiasi Variabel. Variabel berdasarkan arah hubungannya dalam Structural Equation Modeling-Partial Least Square (SEM-PLS) dibagi menjadi dua yaitu variabel eksogen dan variabel endogen (Solihin dan Dwi, 2013; Wibowo, 2014). Variabel eksogen yaitu variabel laten yang mempengaruhi variabel laten lain yang nilainya ditentukan oleh variabel lain diluar model. Ghozali dan Fuad (2012) menyatakan bahwa Jika suatu variabel tidak dipengaruhi oleh variabel lainnya dalam model, maka dalam SEM disebut variabel eksogen (tidak dikenai anak panah). Sementara itu, variabel endogen merupakan variabel laten yang dipengaruhi oleh variabel laten lain dalam suatu model penelitian. Solihin dan Dwi (2013) menyatakan variabel endogen sebagai variabel laten yang nilainya ditentukan oleh variabel lain didalam model (dikenai anak panah dan atau memanah). Variabel eksogen dalam penelitian ini yaitu iklim organisasi $(\xi)$. Sementara itu variabel endogen dalam penelitian ini yaitu stres kerja $\left(\eta_{1}\right)$ dan kinerja karyawan $\left(\eta_{2}\right)$.

Iklim organisasi dalam penelitian ini diukur melalui lima indikator yaitu : (a) tingkat partisipasi diperbolehkan dalam menetapkan tujuan dan standar kinerja serta reward yang dirasakan oleh karyawan; (b) kejelasan kebijakan serta prosedur organisasi dan kejelasan tujuan serta tugas-tugas yang ada pada organisasi; (c) hubungan interpersonal antara bawahan dan orang lain dalam organisasi termasuk manajemen; (d) standar kinerja, tingkat kesulitan dalam mencapai tujuan, dan tekanan untuk kinerja; (e) tanggung jawab individu dan otonomi. Pengukuran iklim organisasi menggunakan instrumen dari Schnake (1983) yang terdiri dari 30 item pernyataan. Salah satu contoh pernyataan tersebut adalah "Dalam perusahaan ini, kinerja dievaluasi secara berkala terhadap tujuan dan standar yang 
telah disepakati”. Alternatif jawaban atas daftar pernyataan tersebut menggunakan skala Likert dengan lima poin. Skor satu mengindikasikan iklim organisasi yang sangat tidak sehat dan skor lima mengindikasikan iklim organisasi yang sangat sehat.

Stres kerja dalam penelitian ini diukur menggunakan tiga indikator yaitu (a) gejala fisiologis; (b) gejala psikologis; (c) gejala perilaku. Pengukuran stres kerja menggunakan instrumen dari Rahmawati (2009) yang telah dimodifikasi oleh Abdillah (2013) yang terdiri dari 15 item pernyataan. Salah satu contoh pernyataan tersebut adalah "saya sering mengalami gangguan pencernaan akibat bekerja". Alternatif jawaban atas daftar pernyataan tersebut menggunakan skala Likert dengan lima poin. Skor satu mengindikasikan stress yang sangat rendah dan skor lima mengindikasikan stres kerja yang sangat tinggi.

Kinerja karyawan dalam penelitian ini diukur menggunakan sepuluh indikator yaitu (a) pengetahuan; (b) komunikasi; (c) pertimbangan; (d) keterampilan manajerial; (e) kualitas kerja; (f) kerja tim; (g) keterampilan antarpribadi; (h) inisiatif; (i) kreativitas; (j) pemecahan masalah. Pengukuran kinerja menggunakan instrumen dari Noe et al. (2011) yang terdiri dari sepuluh item pernyataan dan diisi oleh atasan langsung karyawan. Salah satu contoh pernyataan tersebut adalah "Pengetahuan karyawan tentang pekerjaan". Alternatif jawaban atas daftar pernyataan tersebut menggunakan skala Likert dengan lima poin. Skor satu mengindikasikan kinerja karyawan dibawah rata-rata dan skor lima mengindikasikan kinerja karyawan diatas rata-rata.

Analisis Data. Pengujian hipotesis dalam penelitian ini menggunakan SEM-PLS melalui software SmartPLS Versi 2.0 M3. PLS merupakan analisis persamaan struktural (SEM) berbasis varian yang secara simultan dapat melakukan evaluasi terhadap model pengukuran sekaligus model struktural. Salah satu alasan penggunaan analisa SEM dalam suatu penelitian adalah terdapatnya variabel yang tidak dapat diukur secara langsung (unobserved variable) sehingga variabel tersebut diukur menggunakan indikator (Wibowo, 2014).

PLS merupakan metode analisis yang powerfull dan sering juga disebut sebagai soft modeling karena mampu menguji data yang memiliki jumlah sampel yang kecil (Latan dan Ghozali, 2012). Analisis PLS terdiri dari dua langkah (Hair et al., 2012; Hair et al., 2014): langkah pertama adalah melakukan evaluasi terhadap model pengukuran (outer model) dan langkah kedua adalah melakukan evaluasi terhadap model struktrual (inner model).

Evaluasi terhadap model pengukuran dilakukan melalui uji validitas dan reliabilitas. Uji validitas dilakukan untuk mengetahui kemampuan instrumen penelitian mengukur apa yang seharusnya diukur (tujuan yang diinginkan). Hal ini menunjukkan bahwa instrumen pengukuran mengukur secara valid konsep yang diuji dalam model penelitian (Hartono, 2011; Abdillah dan Hartono, 2015). Uji validitas dievaluasi melalui analisis faktor konfimatori (confimatory factor analysis) dengan menguji validitas konvergen dan validitas diskriminan (Latan dan Ghozali, 2012).

Validitas konvergen berhubungan dengan prinsip bahwa pengukur-pengukur (indikator) dari suatu konstruk seharusnya berkorelasi tinggi dan memiliki skor loading yang cukup. Validitas tidak hanya ditunjukkan pada skor loading tetapi juga oleh konvergensi seluruh indikator pengukur di suatu konstruk (Hartono, 2011; Abdillah dan Hartono, 2015; Hartono, 2015). Pengujian validitas konvergen dapat dilakukan dengan melihat nilai dari AVE dan communality. Apabila nilai AVE dan communality yang 
dihasilkan oleh semua konstruk lebih dari 0,50 maka konstruk memenuhi persyaratan validitas konvergen (Hair et al., 2014).

Sementara itu, validitas diskriminan berhubungan dengan prinsip bahwa pengukurpengukur (instrumen) konstruk yang berbeda seharusnya tidak berkorelasi dengan tinggi. Maksudnya, instrumen-instrumen di suatu konstruk akan berkorelasi tinggi dengan konstruknya dan berkorelasi rendah bahkan tidak berkorelasi dengan konstruk lain. Validitas tercapai tidak hanya ketika skor loading memenuhi kriteria tetapi juga diskriminasi korelasi instrumen-instrumen di suatu konstruk dengan konstruk yang lain (Hartono, 2011; Abdillah dan Hartono, 2015). Pengujian validitas diskriminan dapat dilihat dari akar kuadrat AVE untuk tiap konstruk harus lebih besar dari korelasi antar konstruk dalam model penelitian (Hair et al., 2012).

Selanjutnya, uji reliabilitas digunakan untuk mengukur konsistensi alat ukur dalam mengukur suatu konsep atau dapat juga digunakan untuk mengukur konsistensi responden dalam menjawab item pertanyaan dalam kuesioner atau instrumen penelitian (Hartono, 2011; Abdillah dan Hartono, 2015; Hartono, 2015). Pengujian reliabilitas dapat dilihat dari nilai cronbach's alpha atau nilai composite reliability. Apabila nilai cronbach's alpha atau nilai composite reliability yang dihasilkan diatas atau sama dengan 0,70 maka semua konstruk dapat dikatakan reliabel (Solihin dan Ratmono, 2013).

Tabel 1. Ringkasan Rule of Thumb Evaluasi Outer Model dalam SEM-PLS

\begin{tabular}{cll}
\hline Uji & \multicolumn{1}{c}{ Paramter } & \multicolumn{1}{c}{ Rule of Thumb } \\
\hline Validitas Konvergen & Average Variance Extracted (AVE) & Lebih dari 0,50 \\
& Communality & Lebih dari 0,50 \\
Validitas Diskriminan & Akar kuadrat AVE dan korelasi antar & Akar kuadrat AVE > korelasi \\
& variabel laten & antar variabel laten \\
Reliabilitas & Cronbach's aplha & Lebih dari 0,70 \\
& Composite reliability & Lebih dari 0,70 \\
\hline
\end{tabular}

Sumber: diadopsi dari Hartono (2011); Latan dan Ghozali (2012); Hair et al. (2014); Abdillah dan Hartono (2015)

Evaluasi terhadap model struktural dilakukan untuk memprediksi hubungan kausalitas antar variabel dan membuktikan hipotesis. Untuk membuktikan hipotesis ini digunakan kriteria apabila nilai T-Statistiknya diatas 2,58 (level alpha satu persen), diatas 1,96 (level alpha lima persen) atau diatas 1,65 (level alpha sepuluh persen), maka dapat dikatakan bahwa hipotesis dalam penelitian ini diterima (Latan dan Ghozali, 2012). Untuk membuktikan peran mediasi stres kerja dalam pengaruh iklim organisasi terhadap kinerja karyawan digunakan uji Sobel (Sobel, 1982; Baron dan Kenny, 1986; Preacher dan Hayes, 2004; Solihin dan Ratmono, 2013). Selanjutnya, untuk melihat apakah stres kerja termasuk pemediasi penuh atau parsial digunakan uji mediasi dengan prosedur Baron dan Kenny (1986).

Menurut Baron dan Kenny (1986), untuk mengetahui apakah stres kerja merupakan variabel mediasi parsial atau sempurna maka model dalam penelitian ini diuraikan menjadi dua. Model pertama yaitu pengaruh iklim organisasi terhadap kinerja tanpa stres kerja sebagai variabel mediasi. Selanjutnya, model kedua yaitu pengaruh iklim organisasi terhadap kinerja melalui stres kerja sebagai variabel mediasi. Persyaratan efek mediasi yang harus dipenuhi yaitu (Baron dan Kenny, 1986; Kock, 2011; Solihin dan Ratmono, 2013) koefisien jalur pada model pertama harus signifikan. Dalam model kedua, koefisien 
jalur pengaruh iklim organisasi terhadap stres kerja dan stres kerja terhadap kinerja harus signifikan. Selanjutnya, jika koefisien jalur pengaruh iklim organisasi terhadap kinerja pada model kedua menjadi berkurang dari model pertama dan tidak signifikan maka dapat dijelaskan bahwa stres kerja merupakan variabel mediasi sempurna (full mediation). Sementara itu, jika koefisien jalur pengaruh iklim organisasi terhadap kinerja pada model kedua menjadi berkurang dari model pertama namun tetap signifikan maka dapat dijelaskan bahwa stres kerja merupakan variabel mediasi parsial (partial mediation).

Tabel 2. Ringkasan Rule of Thumb Evaluasi Inner Model dalam SEM-PLS

\begin{tabular}{cl}
\hline Kriteria & \multicolumn{1}{c}{ Rule of Thumb } \\
\hline Signifikansi & T-Satistik $>1,65$ (alpha 10 persen); T-Satistik $>1,96$ (alpha 5 persen); T- \\
& Satistik $>2,58$ (alpha 1 persen) \\
Effect Size $\left(f^{2}\right)$ & $0,02($ lemah/weak); 0,15 (sedang/moderate); 0,35 (kuat/strong)
\end{tabular}

Sumber: diadopsi dari Cohen (1988) Chin (1998) Latan dan Ghozali (2012)

\section{HASIL DAN PEMBAHASAN}

Demografi Responden. Sebelum melakukan analisis data dengan mengevaluasi model pengukuran (outer model) dan model struktrual (inner model), maka dilakukan analisis statistik deskriptif yang terdiri dari demografi responden dan deskriptif variabel penelitian. Deskripsi demografi responden dalam penelitian ini menjelaskan karakteristik responden yang terdiri dari jenis kelamin, usia, masa kerja, dan tingkat pendidikan. Responden yang berjenis kelamin wanita sebanyak 26 orang $(57,78$ persen) dan pria sebanyak 19 orang (42,22 persen). Dalam hal usia, responden dengan usia antara 26 tahun hingga 35 tahun merupakan responden dengan jumlah terbanyak yaitu 21 orang (46,67 persen), dikuti dengan responden yang memiliki usia antara 36 hingga 55 tahun sebanyak 16 orang $(35,56$ persen), dan usia diatas 55 tahun sebanyak 5 orang (11,11 persen). Sementara itu, responden dengan jumlah paling sedikit adalah yang memiliki usia dibawah 25 tahun yaitu sebanyak 3 orang $(6,67$ persen). Sebanyak 27 responden (60,00 persen) memiliki masa kerja antara 1 hingga 5 tahun, 11 responden (24,44 persen) memiliki masa kerja 6 hingga 10 tahun, 5 responden $(11,11$ persen) memiliki masa kerja diatas 10 tahun, dan 2 responden (4,44 persen) memiliki masa kerja dibawah 1 tahun. Selanjutnya, sebagian besar responden memiliki tingkat pendidikan strata satu (S1) yaitu sebanyak 27 orang (60,00 persen), diikuti dengan responden yang memiliki tingkat pendidikan lainnya sebanyak 12 orang $(26,67$ persen), diploma sebanyak 4 orang (8,89 persen), dan strata dua (S2) sebanyak 2 orang $(4,44$ persen).

Deskriptif Variabel Penelitian. Deskriptif variabel dalam penelitian ini digunakan untuk memberikan gambaran tentang tanggapan responden mengenai variabel-variabel penelitian yang menunjukkan angka minimum, maksimum, rata-rata serta standar deviasi. Deskripsi jawaban responden tentang variabel-variabel penelitian yang diukur yaitu iklim organisasi, kinerja karyawan dan stres kerja yang dapat dilihat pada Tabel 1.

Iklim organisasi dalam penelitian ini diukur dengan tiga puluh item pernyataan menggunakan skala likert lima poin, mulai dari poin satu (sangat tidak setuju) hingga poin lima (sangat setuju). Kisaran teoritis variabel iklim organsiasi karyawan adalah 30 hingga 180, dimana skor yang paling rendah mengindikasikan iklim organisasi sangat tidak 
kondusif, dan skor yang paling tinggi mengindikasikan iklim organisasi sangat kondusif. Hasil pengukuran menunjukkan kisaran sesungguhnya variabel iklim organisasi adalah 81 hingga 120 dengan standar deviasi 10,84. Hal ini mengindikasikan frekuensi iklim organisasi adalah bervariasi. Selanjutnya rata-rata sebesar 94,96 hanya sedikir lebih besar dari skor rata-rata total teoritis yaitu sebesar 90 (30 dikali 3) mengindikasikan secara ratarata persepsi responden terhadap iklim organisasi cukup kondusif (sehat).

Tabel 3. Deskripsi Variabel Penelitian

\begin{tabular}{ccccc}
\hline Variabel & Kisaran Teoritis & $\begin{array}{c}\text { Kisaran } \\
\text { Sesungguhnya }\end{array}$ & Mean & $\begin{array}{c}\text { Standar } \\
\text { Deviasi }\end{array}$ \\
\hline Iklim Organisasi & $30-150$ & $81-120$ & 94,96 & 10,84 \\
Kinerja Karyawan & $10-50$ & $32-50$ & 40,77 & 4,64 \\
Stres Kerja & $15-75$ & $24-56$ & 38,44 & 8,20 \\
\hline
\end{tabular}

Kinerja karyawan dalam penelitian ini diukur dengan sepuluh item pernyataan menggunakan skala likert lima poin, mulai dari poin satu (sangat kurang) hingga poin lima (sangat baik). Kisaran teoritis variabel kinerja karyawan adalah 10 hingga 50, dimana skor yang paling rendah mengindikasikan kinerja karyawan dibawah rata-rata, dan skor yang paling tinggi mengindikasikan kinerja karyawan diatas rata-rata. Hasil pengukuran menunjukkan kisaran sesungguhnya variabel kinerja karyawan adalah 32 hingga 50 dengan standar deviasi 4,64. Hal ini mengindikasikan frekuensi kinerja karyawan adalah bervariasi. Selanjutnya rata-rata sebesar 40,77 yang lebih besar dari skor rata-rata total teoritis sebesar 30 (10 dikali 3) mengindikasikan secara rata-rata responden memiliki kinerja diatas rata-rata.

Stres kerja dalam penelitian ini diukur dengan lima belas item pernyataan menggunakan skala likert lima poin, mulai dari poin satu (sangat tidak setuju) hingga poin lima (sangat setuju). Kisaran teoritis variabel stres kerja karyawan adalah 15 hingga 75, dimana skor yang paling rendah mengindikasikan stres kerja karyawan sangat rendah, dan skor yang paling tinggi mengindikasikan stres kerja karyawan sangat tinggi. Hasil pengukuran menunjukkan kisaran sesungguhnya variabel stres kerja adalah 24 hingga 56 dengan standar deviasi 8,20. Hal ini mengindikasikan frekuensi stres kerja karyawan adalah bervariasi. Selanjutnya rata-rata sebesar 38,44 yang sedikit lebih kecil dari skor rata-rata total teoritis sebesar 45 (15 dikali 3 ) mengindikasikan secara rata-rata responden memiliki tingkat stres kerja yang rendah.

Evaluasi Model Pengukuran. Setelah melakukan analisis statistik deskriptif selanjutnya dilakukan analisis data penelitian melalui dua tahap. Tahap pertama adalah melakukan evaluasi terhadap model pengukuran (outer model) dengan cara menguji validitas dan reliabilitas untuk setiap variabel penelitian. Selanjutnya, tahap kedua adalah melakukan evaluasi terhadap model struktrual (inner model). Evaluasi terhadap outer model dalam penelitian ini bertujuan untuk melihat apakah instrumen yang digunakan untuk variabel iklim organisasi, kinerja karyawan dan stres kerja dalam penelitian ini memiliki tingkat ketepatan dan akurasi serta konsistensi yang baik (Hartono, 2011; Abdillah dan Hartono, 2015). Evaluasi terhadap outer model dalam PLS dilakukan melalui uji validitas konvergen, validitas diskriminan, dan reliabilitas. 
Tabel 4. Hasil AVE, Composite Reliability, Cronbach Alpha dan Communality

\begin{tabular}{ccccc}
\hline Variabel & AVE & $\begin{array}{c}\text { Composite } \\
\text { Reliability }\end{array}$ & $\begin{array}{c}\text { Cronbachs } \\
\text { Alpha }\end{array}$ & Communality \\
\hline Iklim Organisasi & 0,527806 & 0,970994 & 0,969545 & 0,527806 \\
Kinerja Karyawan & 0,700892 & 0,958956 & 0,952189 & 0,700892 \\
Stres Kerja & 0,666170 & 0,966983 & 0,962165 & 0,666170 \\
\hline
\end{tabular}

Pada Tabel 4 dapat dilihat bahwa nilai AVE dan communality variabel iklim organisasi, kinerja karyawan dan stres kerja diatas 0,50. Hasil ini menjelaskan bahwa probabilitas instrumen-instrumen setiap variabel (baik itu iklim organisasi, kinerja karyawan dan stres kerja) masuk ke variabel lain lebih rendah (kurang dari 50 persen) sehingga probabilitas instrumen-instrumen tersebut konvergen dan masuk di variabel yang dimaksud lebih besar, yaitu diatas 0,50 persen (Hartono, 2011; Abdillah dan Hartono, 2015). Sehingga dapat disimpulkan bahwa seluruh instrumen setiap variabel dalam penelitian ini memenuhi persyaratan validitas konvergen (Hair et al., 2014).

Pada Tabel 5 dapat dilihat bahwa nilai akar kuadrat dari AVE lebih besar dibandingkan dengan nilai korelasi antar variabel pada kolom yang sama. Hasil ini menjelaskan bahwa skor loading masing-masing instrumen pada suatu variabel (baik itu iklim organisasi, kinerja karyawan dan stres kerja) akan berbeda dengan instrumeninstrumen tersebut di variabel lain dan mengumpul pada variabel yang dimaksud (Hartono, 2011; Abdillah dan Hartono, 2015). Sehingga, dapat disimpulkan bahwa seluruh instrumen setiap variabel yang terdiri dari iklim organisasi, kinerja karyawan dan stres kerja pada model penelitian ini memenuhi persyaratan validitas diksriminan (Hair et al., 2012).

Tabel 5. Perbandingan Nilai Korelasi Antar Variabel dengan Akar Kuadrat AVE

\begin{tabular}{cccc}
\hline Variabel & Iklim Organisasi & Kinerja Karyawan & Stres Kerja \\
Iklim Organisasi & 0,726503 & & \\
Kinerja Karyawan & 0,456936 & 0,837193 & \\
Stres Kerja & $-0,452367$ & $-0,553517$ & 0,816192 \\
\hline
\end{tabular}

Selanjutnya, nilai cronbach's alpha atau composite reliability variabel iklim organisasi, kinerja karyawan dan stres kerja diatas 0,70 (tabel 4). Hasil ini mejelaskan bahwa seluruh instrumen variabel yang terdiri dari iklim organisasi, kinerja karyawan dan stres kerja pada model penelitian ini memiliki akurasi dan konsistensi dalam mengukur konstruk (Hartono, 2011; Latan dan Ghozali, 2012; Solihin dan Ratmono, 2013; Abdillah dan Hartono, 2015). Ketiga hasil evaluasi terhadap outer model tersebut menjelaskan bahwa instrumen-instrumen yang digunakan untuk variabel iklim organisasi, kinerja karyawan dan stres kerja dalam penelitian ini memiliki tingkat ketepatan dan akurasi serta konsistensi yang baik (Hartono, 2011; Abdillah dan Hartono, 2015), karena memenuhi persyaratan uij validitas konvergen, validitas diskriminan, dan reliabilitas.

Evaluasi Model Struktural. Evaluasi terhadap model struktural dalam penelitian ini bertujuan untuk memprediksi hubungan kausalitas antar variabel yang telah 
dihipotesiskan. Hasil evaluasi model struktural dalam penelitian ini menunjukkan bahwa hipotesis pertama $\left(\mathrm{H}_{1}\right)$ didukung secara statistik dengan nilai T-Statistik signifikan pada level alpha 10 persen yaitu sebesar 1,773 (diatas 1,65) dengan koefisien jalur sebesar 0,260 . Hal ini membuktikan bahwa iklim organisasi berpengaruh positif terhadap kinerja karyawan. Hasil penelitian ini konsisten dengan penelitian sebelumnya (Adeyemi, 2008; Selamat et al., 2013; Suandi et al., 2014; He et al., 2015) yang menjelaskan bahwa semakin kondusif (sehat) iklim suatu organisasi, maka semakin tinggi pula tingkat kinerja individu karyawan. Sebaliknya, semakin tidak kondusif (tidak sehat) iklim suatu organisasi, maka semakin rendah tingkat kinerja individu karyawan.

Iklim organisasi memainkan peran langsung dalam meningkatkan perilaku dan kinerja individu (He et al., 2015). Iklim organisasi yang kondusif (sehat) mampu menjaga dan melestarikan motivasi karyawan dan kinerja tinggi (Miller, 2002). Hal ini cukup beralasan karena iklim organisasi yang sehat dan cenderung diterima oleh karyawan merupakan salah satu faktor paling penting yang mempengaruhi dan berdampak pada kontribusi dan keterlibatan karyawan di tempat kerja (Shadur et al., 1999). Perusahaan yang mampu mengembangkan iklim organisasi yang positif dan konstruktif (sehat) dapat mendorong dan mendukung motivasi karyawan dan sebagai hasilnya meningkatkan kinerja (Suliman dan Harethi, 2013).

Tabel 6. Hasil Evaluasi Model Struktural

\begin{tabular}{|c|c|c|c|c|c|}
\hline \multicolumn{2}{|c|}{ Uji Hipotesis } & $\begin{array}{l}\text { Prediksi } \\
\text { Tanda }\end{array}$ & $\begin{array}{l}\text { Koefisien } \\
\text { Jalur }\end{array}$ & $\begin{array}{l}\text { Standard } \\
\text { Error }\end{array}$ & $\begin{array}{c}\mathrm{T} \\
\text { Statistics }\end{array}$ \\
\hline \multicolumn{2}{|c|}{$\begin{array}{l}\text { Iklim Organsiasi } \rightarrow \text { Kinerja } \\
\text { Karyawan }\end{array}$} & + & 0,260 & 0,146 & $1,773^{*}$ \\
\hline \multicolumn{2}{|c|}{ Iklim Organisasi $\rightarrow$ Stres Kerja } & - & $-0,452$ & 0,097 & $4,563 * * *$ \\
\hline \multicolumn{2}{|c|}{ Stres Kerja $\rightarrow$ Kinerja Karyawan } & - & $-0,436$ & 0,144 & $3,023 * * *$ \\
\hline \multicolumn{6}{|c|}{ Sumber: Data Olahan Smart PLS 2.0 M3 (2015) } \\
\hline$*$ & \multicolumn{5}{|c|}{ Secara statistik signifikan pada level alpha $10 \%$} \\
\hline$* *$ & \multicolumn{5}{|c|}{ Secara statistik signifikan pada level alpha $5 \%$} \\
\hline$* * *$ & \multicolumn{5}{|c|}{ Secara statistik signifikan pada level alpha $1 \%$} \\
\hline
\end{tabular}

Hipotesis kedua $\left(\mathrm{H}_{2}\right)$ didukung secara statistik dengan nilai T-Statistik signifikan pada level alpha 1 persen yaitu sebesar 4,563 (diatas 2,58) dengan koefisien jalur sebesar 0,436 . Hal ini membuktikan bahwa stres kerja berpengaruh negatif terhadap kinerja karyawan. Hasil penelitian ini konsisten dengan penelitian sebelumnya (Bashir dan Ramay, 2010; Cholilawati, 2010; Leung et al., 2011; Abdillah, 2013; Suandi et al., 2014; Rangriz dan Pashootanizadeh, 2014; Goswami, 2015) yang menjelaskan bahwa semakin tinggi tingkat stres kerja karyawan, maka semakin rendah tingkat kinerja individu karyawan. Sebaliknya, semakin rendah tingkat stres kerja karyawan, maka semakin tinggi tingkat kinerja individu karyawan.

Karyawan yang menderita stres tinggi akan mencoba untuk menarik dirinya agar bisa keluar dari penyebab stres (stressor). Selain ingin meninggalkan perusahaan, karyawan yang menderita stres akan cenderung menciptakan masalah bagi perusahaan seperti ketidakefisienan dalam kinerja, pemborosan sumber daya operasional, menjadi penyebab kendala kerja bagi karyawan lainnya dan lain sebagainya (Goswami, 2015). Hal ini cukup beralasan karena karyawan yang menderita stres yang tinggi sulit untuk 
berkosentrasi, kurang bersemangat dalam bekerja (Robbins, 2007) sehingga menurunkan kualitas dan kuantitas hasil pekerjaan (Wu, 2011).

Hipotesis ketiga $\left(\mathrm{H}_{1 \mathrm{a}}\right)$ didukung secara statistik dengan nilai T-Statistik signifikan pada level alpha 1 persen yaitu sebesar 3,023 (diatas 2,58) dengan koefisien jalur sebesar 0,452 . Hal ini membuktikan bahwa iklim organisasi berpengaruh negatif terhadap stres kerja karyawan. Hasil penelitian ini konsisten dengan penelitian sebelumnya (Ahghar, 2008; Sert et al., 2014) yang menjelaskan bahwa semakin sehat iklim suatu organisasi maka semakin rendah tingkat stres kerja karyawan. Sebaliknya, semakin tidak sehat iklim suatu organisasi, maka semakin tinggi tingkat stres kerja karyawan.

Iklim organisasi merupakan salah satu penyebab munculnya stres kerja karyawan (Robbins, 2007; Wagner dan Hollenbeck, 2010; Luthans, 2011; Gibson et al., 2012). Hal ini cukup beralasan karena karyawan yang bekerja dalam iklim organisasi tertutup dan tidak sehat akan cenderung memiliki emosi dan perasaan negatif terhadap pekerjaannya. Emosi dan perasaan negatif tersebut tampak pada ketidakpuasan, tekanan psikologis, melalaikan, ketidakpedulian, dan akhirnya akan menyebabkan karyawan menghindari pekerjaan yang mengarah ke stres kerja (Ahghar, 2008).

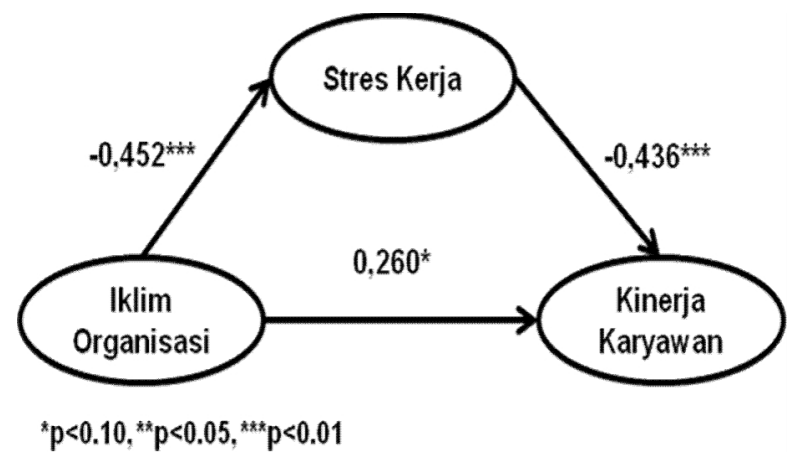

Gambar 2. Hasil Evaluasi Model Struktural

Pengujian hipotesis keempat $\left(\mathrm{H}_{1 \mathrm{~b}}\right)$ dilakukan dengan uji sobel (Baron dan Kenny, 1986; Preacher dan Hayes, 2004; Solihin dan Ratmono, 2013) dan effect size (Cohen, 1988). Dari hasil perhitungan uji sobel ditemukan nilai t sebesar 2,495. Sehingga hipotesis keempat $\left(\mathrm{H}_{1 \mathrm{~b}}\right)$ dalam penelitian ini didukung secara statistik dengan nilai signifikan pada level alpha 1 persen (diatas 2,58). Hal ini membuktikan bahwa iklim organisasi berpengaruh tidak langsung terhadap kinerja karyawan melalui stres kerja karyawan. Persepsi karyawan tentang karakteristik organisasi yang tercermin dalam kebijakan, praktik dan kondisi yang ada di lingkungan kerja yang sehat akan menimbulkan emosi positif yang pada akhirnya akan mengurangi tingkat stres kerja yang dirasakan oleh karyawan (Schanke, 1983; Ahghar, 2008). Selanjutnya, karyawan yang memiliki tingkat stres yang rendah akan mampu memberikan hasil kerja yang baik dan maksimal (Bashir dan Ramay, 2010; Cholilawati, 2010; Abdillah, 2013; Suandi et al., 2014; Goswami, 2015).

Tabel 7. Pengaruh Langsung Iklim Organisasi Terhadap Kinerja Tanpa Variabel Stres

\begin{tabular}{ccccc}
\hline \multicolumn{4}{c}{ Kerja } & \\
Uji Hipotesis & $\begin{array}{c}\text { Prediksi } \\
\text { Tanda }\end{array}$ & $\begin{array}{c}\text { Koefisien } \\
\text { Jalur }\end{array}$ & $\begin{array}{c}\text { Standard } \\
\text { Error }\end{array}$ & T Statistics \\
\hline Iklim Organsiasi $\rightarrow$ Kinerja Karyawan & + & 0,473 & 0,116 & $4,066^{* * *}$ \\
\hline
\end{tabular}


* : $\quad$ : Secara statistik signifikan pada level alpha $10 \%$

** : Secara statistik signifikan pada level alpha 5\%

*** : Secara statistik signifikan pada level alpha $1 \%$

Koefisien jalur pengaruh langsung iklim organisasi terhadap kinerja karyawan tanpa adanya variabel mediasi stres kerja adalah sebesar 0,473 dan signifikan pada level alpha 1 persen yaitu sebesar 4,066 (diatas 2,58). Namun, ketika pengaruh tersebut dimediasi oleh stres kerja, koefisien jalurnya berkurang besarnya menjadi 0,260 dan tetap signifikan pada level alpha 10 persen yaitu sebesar 1,773 (diatas 1,65). Hal tersebut menjelaskan bahwa stres kerja memediasi parsial (partial mediation) pengaruh tidak langsung iklim organisasi terhadap kinerja karyawan. Hal ini sesuai dengan argumen Baron dan Kenny (1986) yang menjelaskan bahwa mediasi parsial terjadi ketika pengaruh langsung yang signifikan tetap signifikan ketika dikendalikan oleh variabel mediasi.

Bentuk partial mediation ini menunjukkan bahwa stres kerja bukan satu-satunya variabel pemediasi dalam pengaruh tidak langsung iklim organisasi terhadap kinerja karyawan (Baron dan Kenny, 1986; Preacher dan Hayes, 2004; Kock, 2011; Solihin dan Ratmono, 2013). Kasus mediasi parsial dalam penelitian perilaku sangat mungkin terjadi karena dalam memprediksi perilaku manusia masih ada beberapa terdapat alternatif penyebab (Malik et al., 2010).

Tabel 8. Hasil R Square

\begin{tabular}{|c|c|c|}
\hline Variabel & $\begin{array}{c}\mathrm{R}^{2} \\
\text { (Stres Kerja Sebagai Variabel } \\
\text { Mediasi) }\end{array}$ & $\begin{array}{c}\mathrm{R}^{2} \\
\text { (Tanpa Stres Kerja Sebagai } \\
\text { Variabel Mediasi) }\end{array}$ \\
\hline Kinerja Karyawan & 0,360016 & 0,223967 \\
\hline
\end{tabular}

Selanjutnya, effect size digunakan untuk melihat seberapa besar pengaruh variabel stres kerja sebagai variabel mediasi. Nilai effect size $\left(f^{2}\right)$ dihitung dengan menggunakan rumus (Cohen, 1988):

$$
f^{2}=\frac{\left(R^{2} \text { with mediator }-R^{2} \text { without mediator }\right)}{\left(1-R^{2} \text { with mediator }\right)}
$$

Angka $\mathrm{R}^{2}$ with mediator diperoleh dari $\mathrm{R}^{2}$ variabel kinerja karyawan (variabel endogen) dengan memasukkan variabel mediasi stres kerja. Sedangkan angka $\mathrm{R}^{2}$ without mediator diperoleh dari angka $\mathrm{R}^{2}$ variabel kinerja karyawan tanpa memasukkan variabel stres kerja sebagai variabel mediasi (dapat dilihat pada tabel 6). Dari hasil perhitungan ditemukan nilai effect size sebesar 0,213. Nilai tersebut menjelaskan bahwa stres kerja sebagai variabel mediasi memiliki pengaruh moderate nearly strong atau sedang nyaris kuat pada level struktural (Cohen, 1988; Chin, 1998; Latan dan Ghozali, 2012).

Hasil penelitian ini secara teoritis dapat menjadi rujukan bagi peneliti selanjutnya yang membangun sebuah model mengenai pengaruh tidak langsung iklim orgainisasi terhadap kinerja melalui stres kerja karyawan. Sementara itu, secara praktis, hasil penelitian ini dapat menjadi masukan bagi pimpinan pada PT. Adei Plantation \& Industry Head Office Pekanbaru Riau tentang pentingnya aspek iklim organisasi yang sehat guna mengurangi tingkat stres kerja sehingga menghasilkan kinerja yang baik. Berdasarkan bukti empiris, perusahaan yang memiliki iklim kerja yang kondusif (sehat) akan 
cenderung berdampak pada tingkat stres kerja yang rendah dan memiliki hasil kerja karyawan yang baik. Untuk menciptakan hasil iklim kerja yang kondusif perusahaan perlu memperhatikan aspek keadilan (Sert et al., 2014) dalam memutuskan kebijakan-kebijakan manajerial yang akan berdampak pada persepsi karyawan tentang iklim organisasi seperti partisipasi karyawan dalam dalam menetapkan tujuan dan standar kinerja, reward, dukungan organisasi (organizational support), penetapan standar kinerja, dan tanggung jawab pekerjaan.

\section{PENUTUP}

Simpulan. Hasil penelitian ini menyimpulkan: (1) iklim organisasi berpengaruh positif terhadap kinerja karyawan; (2) stres kerja berpengaruh negatif terhadap kinerja karyawan; (3) iklim organisasi berpengaruh negatif terhadap stres kerja karyawan; (4) iklim organisasi berpengaruh tidak langsung terhadap kinerja karyawan melalui stres kerja; dan (5) stres kerja sebagai variabel mediasi memiliki pengaruh moderat nearly strong atau sedang nyaris kuat pada level struktural.

Hasil penelitian ini memberikan bukti empiris yang menjelaskan bahwa iklim organisasi yang sehat akan memberikan dampak langsung terhadap stres kerja yang rendah dan kinerja karyawan yang tinggi. Sebaliknya, iklim organisasi yang tidak sehat akan memberikan dampak langsung terhadap stres kerja yang tinggi dan kinerja karyawan yang rendah. Dengan menggunakan responden yang berasal dari karyawan pada PT. Adei Plantation \& Industry Head Office Pekanbaru Riau dapat dijelaskan bahwa stres kerja yang rendah mampu menjadi mediasi dalam pengaruh tidak langsung antara iklim organisasi yang sehat terhadap kinerja karyawan yang tinggi. Sebaliknya, stres kerja yang tinggi mampu menjadi mediasi dalam pengaruh tidak langsung antara iklim organisasi yang tidak sehat terhadap kinerja karyawan yang rendah.

Keterbatasan dan Saran. Hasil penelitian ini kurang dapat digeneralisasi secara luas untuk setiap perusahaan di Indonesia karena hanya menggunakan reponden yang berasal dari karyawan sebanyak 45 orang pada PT. Adei Plantation \& Industry Head Office Pekanbaru Riau. Penelitian selanjutnya diharapkan dapat memperluas ruang lingkup penelitian agar tingkat generalisasi penelitian menjadi lebih akurat. Penelitian selanjutnya juga diharapkan menambahkan satu atau lebih jumlah variabel yang diduga dipengaruhi oleh iklim organisasi dan mempengaruhi kinerja karyawan seperti employee motivation (Suliman dan Harethi, 2013), job satisfaction dan organizational commitment (Danish et al., 2015).

\section{DAFTAR RUJUKAN}

Abdillah, M., R. (2013) Pengaruh Dimensi Kecerdasan Emosional Terhadap Stress Kerja dan Kinerja. Tesis Magister Manajemen Universitas Islam Indonesia: Yogyakarta (Tidak Dipublikasikan).

Abdillah, W. dan J. Hartono. (2015) Partial Least Square (PLS): Alternatif Structural Equation Modeling (SEM) dalam Penelitian Bisnis. Yogyakarta: Andi. 
Adeyemi, T. O. (2008) “Organisational Climate and Teachers' Job Performance in Primary Schools in Ondo State, Nigeria: An Analytical Survey". Asian Journal of Information Technology. 7 (4), 138-145.

Aizzat Mohd. Nasurdin, T. Ramayah, Y. C. Beng. (2006) "Organizational structure and organizational climate as potential predictors of job stress: Evidence from Malaysia”. International Journal of Commerce and Management. 16 (2), 116-129.

Baron, R. M, dan D. A. Kenny. (1986) "The Moderator - Mediator Variable Distinction in Social Psychological Research: Conseptual, Strategic, and Statistical Considerations". Journal of Personality and Social Psychology. 51 (6), 1173-1182.

Bashir, U. dan M. I. Ramay. (2010) "Impact of Stress on Employees Job Performance A Study on Banking Sector of Pakistan". International Journal of Marketing Studies. 2 (1), 122-126.

Cholilawati, N. (2010) "Pengaruh Kecerdasan Emosional Terhadap Stress Kerja dan Kinerja Perawat di Rumah Sakit Islam Hidayatullah Yogyakarta". Tesis Magister Manajemen, Universitas Islam Indonesia: Yogyakarta, (Tidak Dipublikasikan).

Chin, W. W. (1998) The Partial Least Squares Approach for Structural Equation Modeling. In G.A. Marcoulides (Ed.), Modern Methods for Busniness Research, London: Lawrence Erlbaum Associates

Cohen, J. (1988) Statistical Power Analysis for The Behavioral Sciences. Hillsdale. New Jersey: Lawrence Earlbaum Associates.

Danish, R. Q., U. Draz, dan H. Y. Ali. (2015) "Impact of Organizational Climate on Job Satisfaction and Organizational Commitment in Education Sector of Pakistan". American Journal of Mobile Systems, Applications and Services. 1 (2), 102-109.

Denison, D. R. (1996) What is the Difference between Organizational Culture and Organizational Climate? A Native's Point of View on a Decade of Paradigm Wars. The Academy of Management Riview. 21 (3) (July), 619-654.

Estrella, E. A. (2014) "Job Stress and Job Performance of The Faculty of Instruction of The College of Education of The Bulacan State University Bustos Campus". International Journal of University Teaching and Faculty Development. 5 (1), 1-10.

Fitriastuti, T. (2013) "Pengaruh Kecerdasan Emosional, Komitmen Organisasi, dan Organizational Citizenship Behavior Terhadap Kinerja Karyawan”. Jurnal Dinamika Manajemen. 4 (2), 103-114.

Gibson, J.L., J. M. Ivancevich, J. H. Donelly Jr., dan R. Konopaske. (2012) Organizations: Behavior, Structure, Process. New York: McGraw-Hill.

Goswami, T. G. (2015) "Job Stress and Its Effect on Employee Performance in Banking Sector". Indian Journal of Commerce \& Management Studies. 6 (2), 51-56.

Hair, J. F., M. Sarstedt, C. M. Ringle, dan J. A. Mena. (2012) "An Assessment of the Use off Partial Least Squares Structural Equation Modeling in Marketing Research", Journal of the Academy of Marketing Science. 40 (1), 414-433.

Hair, J. F., M. Sarstedt, L. Hopkins, V. G. Kuppelwieser. (2014) Partial Least Squares Structural Equation Modeling (PLS-SEM): An Emerging Tool in Business Research. European Business Review. 26 (2), 106-121.

Hartono J. (2011) Konsep dan Aplikasi Structural Equation Modeling Berbasis Varian dalam Penelitian Bisnis. Yogyakarta: UPP STIM YKPN.

Hartono. (2015) Metodologi Penelitian Bisnis: Salah Kaprah dan PengalamanPengalaman. Edisi 6. Yogyakarta: BPFE. 
He, Q., Q. An, dan M. Li. (2015) "How Vocational Delay of Gratification Affects Employees' Job Performance: Organizational Climate as a Moderator". Journal of Service Science and Management. 8 (5) (October), 766-772.

Hockenbury, D. H. dan S. E. Hockenbury. (2010) Psychology. Fifth Edition. New York: Worth.

Jehangir, M., N. Kareem, A. Khan, M. T. Jan. (2011) "Effects of Job Stress on Job Performance \& Job Satisfaction". Interdiciplinary Journal of Contemporary Research in Business. 3 (7) (November), 453-456.

Kock, N. (2011) "Using WarpPLS in e-Collaboration Studies: Mediating Effects, Control and Second Order Variables, and Algorithm Choices". International Journal of eCollaboration. 7 (3) (July-September), 1-13.

Kusmaningtyas, A dan P. O. Priyana. (2012) "The Influence of Compensation and Organization Climate on Work Motivation and Their Impact on Employee Performance of Bank XXX Corporation at Tanjung Perak". Proceeding Seminar Nasional \& Call for Paper (SCA-2). 2 (1) (diperoleh dari: http://jp.feb.unsoed.ac.id/index.php/sca-1/article/view/178/183 diunduh pada 10-102015).

Latan, H. dan I. Ghozali. (2012) Partial Least Squares: Konsep, Teknik dan Aplikasi Menggunakan Program SmartPLS 2.0 M3. Semarang: UNDIP Press.

Leung, M., Y. S. I. Chan, dan C. Dongyu. (2011) Structural linear relationships between job stress, burnout, physiological stress, and performance of construction project managers. Engineering, Construction and Architectural Management. 18 (3), 312328.

Lewin, K., R. Lippitt dan R. K. White. (1939) "Patterns of Aggressive Behavior in Experimentally Created "Social Climates", The Journal of Social Psychology, 10 (2), 269-299.

Luthans, F. (2011) Organizational Behavior: An Evidence-Based Approach. New York: McGraw-Hill.

Malik, O. F., A. Waheed, dan K. U. Malik. (2010) "The Mediating Effects of Job Satisfaction on Role Stressors and Affective Commitment". International Journal of Business and Management. 5 (11) (November), 223-235.

Mangkunegara, A. A. A. P. (2010) Manajemen Sumber Daya Manusia Perusahaan. Bandung : Rosda.

Mangkunegara, A. A. A. P. dan M. Puspita. (2015) "Kecerdasan Emosi, Stres Kerja dan Kinerja Guru SMA”. Jurnal Kependidikan. 4 (2) (November), 142-155.

Miller, J. (2002) Creating a work climate that motivates staff and improves performance. The Manager. 11 (3): 1-21.

Mohsan, F., M. M. Nawaz, M. S. Khan. (2011) "Impact of Stress on Job Performance of Employees Working in Banking Sector of Pakistan". Interdiciplinary Journal of Contemporary Research in Business. 3 (2) (June), 1982-1991.

Mondy, R. W. (2008) Manajemen Sumber Daya Manusia. Edisi Kesepuluh. Jilid 1. Jakarta : Erlangga.

Noe, R. A., J. R. Hollenbeck, B. Gerhart, and P. M. Wright. (2011) Fundamental of Human Resoure Management. Edisi Keempat. New York: McGraw-Hill.

Putra, A. U., E. S. Astuti, dan D. Hamid. (2014) "Pengaruh Iklim Organisasi terhadap Eustress dan Kepuasan Kerja Karyawan (Studi Kasus Pada Karyawan Perum Jasa Tirta I Malang Jawa Timur)”. Jurnal Administrasi Bisnis. 14. (1) (September), 1-10. 
Preacher, K. J. dan A. F. Hayes. (2004) SPSS and SAS Procedurs for Estimating Indirect Effects in Simple Mediation Models. Behavior Research Methods, Instrument \& Computers. 36 (4) (May), 717-731.

Rahmawati, S. (2009) “Analisis Stres Kerja Karyawan pada PT Bank Rakyat Indonesia (Persero) Tbk Cabang Bogor”. Jurnal Manajemen. 1 (1), 111-122.

Rajan, D. (2015) "Stress and Job Performance among Nurses". SCMS Journal of Indian Management. 12 (1), 66-87.

Rangriz, H. dan H. Pashootanizadeh. (2014) "The Relationship between Job Stress, Job Satisfaction, and Employee Performance". Asian Journal of Research in Social Sciences and Humanities. 4 (10) (October), 353-363.

Rivai, V dan D. Mulyadi. (2009) Kepemimpinan dan Perilaku Organisasi. Jakarta: Rajawali Pers.

Robbins, S. R. (2007) Perilaku Organisasi, Edisi Kesepuluh, Cetakan Kedua. Jakarta: Indeks.

Shahzad, K., M. Sarmad, M. Abbas, dan M. A. Khan. (2011) "Impact of Emotional Intelligence (EI) on employee's performance in telecom sector of Pakistan". African Journal of Business Management. 5 (4) (February), 1225-1231.

Schnake, M., E. (1983) An empirical assessment of the effects of affective response in the measurement of organizational climate. Personnel Psychology. 36 (December), 791804.

Selamat, N., N. Z. Samsu, dan N. S. M. Kamalu. (2013) The Impact of Organizational Climate on Teachers' Job Performance. Educational Research eJournal. 2 (1), 71 82.

Sert, A., M. Elçi, T. Uslu, dan I. Şener. (2014) The Effects of Organizational Justice and Ethical Climate on Perceived Work Related Stress. Procedia Social and Behavioral Sciences. 150 (September), 1187-1198.

Shadur, M., R. Kienzle, dan J. J. Rodwell. (1999) The relationship between organizational climate and employee perceptions of involvement. Group \& Organization Management. 24 (4) (December), 479-503.

Sharma, P. (2013) "Study of Organizational Climate and Stress of Police Personnel". International Journal of Advanced Research in Management and Social Sciences. 2 (2) (February), 212-230.

Sobirin, Achmad. (2012) Perilaku Organisasi. Banten: Universitas Terbuka.

Solihin, M. dan D. Ratmono. (2013) Analisis SEM-PLS dengan WarpPLS 3.0, Yogyakarta : Andi.

Suandi T., I. A. Ismail, dan Z. Othman. (2014) "Relationship Between Organizational Climate, Job Stress And Job Performance Officer At State Education Department". International Journal of Education \& Literacy Study. 2 (1) (January), 17-28.

Suliman, A. dan B. A. Harethi. (2013) Perceived work climate and employee performance in public security organizations in the UAE. Transforming Government: People, Process and Policy. 7 (3), 410-424.

Wagner, J. A. and J. R. Hollenbeck. (2010) Organizational Behavior: Securing Competitive Advantage. New York: Routledge

Wibowo, H., S. (2014) SEM With Lisrel, Modul Pelatihan Pusat Pendidiikan dan Pelayanan (P3M) Universitas Indonesia, Depok.

Wirawan. (2008) Budaya dan Iklim Organisasi: Teori Aplikasi dan Penelitian. Jakarta: Salemba Empat. 
Wu, Y. C. (2011) Job Stress and Job Performance Among Employess in Taiwanese Finance Sector: The Role Of Emotional Intelligence. Social Behavior and Personality. Vol. 39 (1), 21-32.

Zalukhu, I. (2013) "Pengaruh Kecerdasan Emosional, Iklim Organisasi, Stres Kerja Terhadap Kinerja Pegawai (Studi Kasus di Kantor Pusat Badan SAR Nasional Jakarta)". Jurnal MIX. 3 (1) (Februari), 1-11. 


\section{Lampiran}

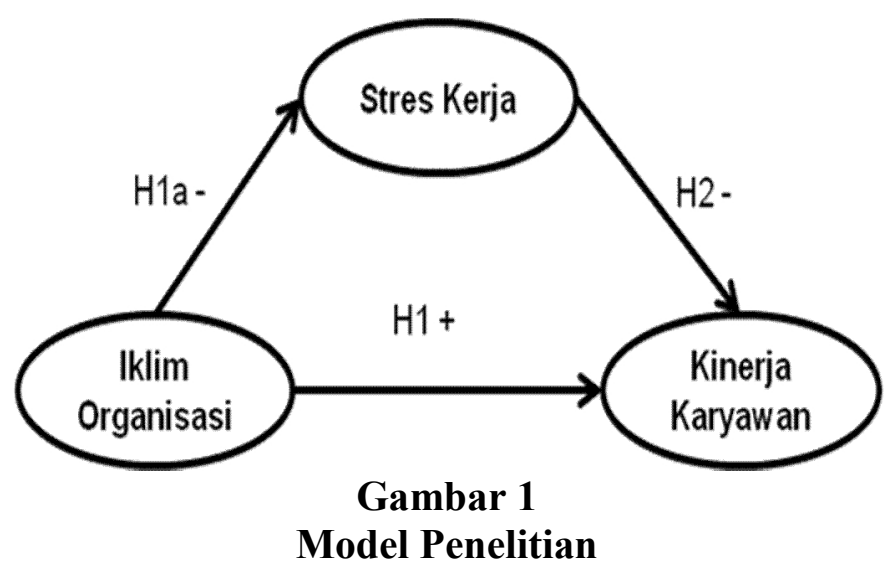

Tabel 1

Ringkasan Rule of Thumb Evaluasi Outer Model dalam SEM-PLS

\begin{tabular}{|c|l|l||}
\hline \multicolumn{1}{|c|}{ Uji } & \multicolumn{1}{|c||}{ Paramter } & \multicolumn{1}{|c||}{ Rule of Thumb } \\
\hline \hline Validitas Konvergen & $\begin{array}{l}\text { Average Variance Extracted } \\
\text { (AVE) }\end{array}$ & Lebih dari 0,50 \\
\cline { 2 - 3 } & Communality & Lebih dari 0,50 \\
\hline Validitas Diskriminan & $\begin{array}{l}\text { Akar kuadrat AVE dan korelasi } \\
\text { antar variabel laten }\end{array}$ & $\begin{array}{l}\text { Akar kuadrat AVE > } \\
\text { korelasi antar variabel laten }\end{array}$ \\
\hline Reliabilitas & Cronbach's aplha & Lebih dari 0,70 \\
\cline { 2 - 3 } & Composite reliability & Lebih dari 0,70 \\
\hline
\end{tabular}

Sumber : diadopsi dari Hartono (2011); Latan dan Ghozali (2012); Hair et al. (2014); Abdillah dan Hartono (2015)

Tabel 2

Ringkasan Rule of Thumb Evaluasi Inner Model dalam SEM-PLS 


\begin{tabular}{|c|l|}
\hline Signifikansi & $\begin{array}{l}\text { T-Satistik }>1,65 \text { (alpha } 10 \text { persen); T-Satistik }>1,96 \text { (alpha } 5 \\
\text { persen); T-Satistik }>2,58 \text { (alpha 1 persen) }\end{array}$ \\
\hline Effect Size $\left(f^{2}\right)$ & 0,02 (lemah/weak); 0,15 (sedang/moderate); 0,35 (kuat/strong) \\
\hline
\end{tabular}

Sumber : diadopsi dari Cohen (1988) Chin (1998) Latan dan Ghozali (2012)

Tabel 3

Deskripsi Variabel Penelitian

\begin{tabular}{|c|c|c|c|c|}
\hline Variabel & $\begin{array}{c}\text { Kisaran } \\
\text { Teoritis }\end{array}$ & $\begin{array}{c}\text { Kisaran } \\
\text { Sesungguhnya }\end{array}$ & Mean & $\begin{array}{c}\text { Standar } \\
\text { Deviasi }\end{array}$ \\
\hline \hline Iklim Organisasi & $30-150$ & $81-120$ & 94,96 & 10,84 \\
\hline Kinerja Karyawan & $10-50$ & $32-50$ & 40,77 & 4,64 \\
\hline Stres Kerja & $15-75$ & $24-56$ & 38,44 & 8,20 \\
\hline
\end{tabular}

Sumber : Data Olahan SPSS Versi 21.00 (2015)

Tabel 4

Hasil AVE, Composite Reliability, Cronbach Alpha dan Communality

\begin{tabular}{|c|c|c|c|c||}
\hline Variabel & AVE & $\begin{array}{c}\text { Composite } \\
\text { Reliability }\end{array}$ & $\begin{array}{c}\text { Cronbachs } \\
\text { Alpha }\end{array}$ & Communality \\
\hline \hline Iklim Organisasi & 0,527806 & 0,970994 & 0,969545 & 0,527806 \\
\hline Kinerja Karyawan & 0,700892 & 0,958956 & 0,952189 & 0,700892 \\
\hline Stres Kerja & 0,666170 & 0,966983 & 0,962165 & 0,666170 \\
\hline \hline
\end{tabular}

Sumber : Data Olahan Smart PLS 2.0 M3 (2015) 
Tabel 5

Perbandingan Nilai Korelasi Antar Variabel dengan Akar Kuadrat AVE

\begin{tabular}{|c|c|c|c||}
\hline Variabel & Iklim Organisasi & Kinerja Karyawan & Stres Kerja \\
\hline \hline Iklim Organisasi & $\mathbf{0 , 7 2 6 5 0 3}$ & & \\
\hline Kinerja Karyawan & 0,456936 & $\mathbf{0 , 8 3 7 1 9 3}$ & \\
\hline Stres Kerja & $-0,452367$ & $-0,553517$ & $\mathbf{0 , 8 1 6 1 9 2}$ \\
\hline
\end{tabular}

Sumber : Data Olahan Smart PLS 2.0 M3 (2015)

Tabel 6

Hasil Evaluasi Model Struktural

\begin{tabular}{|l|c|c|c|c||}
\hline \multicolumn{1}{|c|}{ Uji Hipotesis } & $\begin{array}{c}\text { Prediksi } \\
\text { Tanda }\end{array}$ & $\begin{array}{c}\text { Koefisien } \\
\text { Jalur }\end{array}$ & $\begin{array}{c}\text { Standard } \\
\text { Error }\end{array}$ & $\begin{array}{c}\text { T } \\
\text { Statistics }\end{array}$ \\
\hline Iklim Organsiasi $\rightarrow$ Kinerja Karyawan & + & 0,260 & 0,146 & $1,773^{*}$ \\
\hline Iklim Organisasi $\rightarrow$ Stres Kerja & - & $-0,452$ & 0,097 & $4,563 * * *$ \\
\hline Stres Kerja $\rightarrow$ Kinerja Karyawan & - & $-0,436$ & 0,144 & $3,023 * * *$ \\
\hline
\end{tabular}

Sumber : Data Olahan Smart PLS 2.0 M3 (2015)

* : : Secara statistik signifikan pada level alpha $10 \%$

** : Secara statistik signifikan pada level alpha 5\%

*** : Secara statistik signifikan pada level alpha $1 \%$

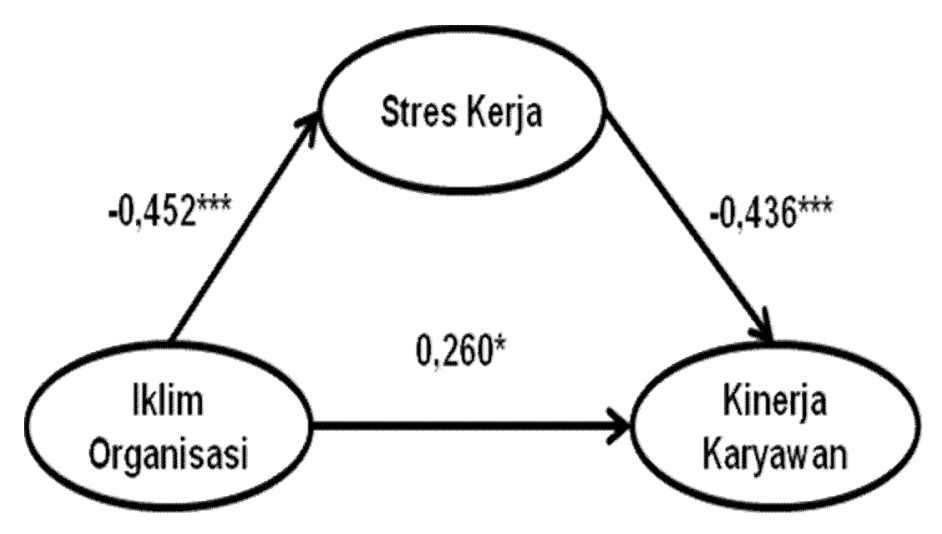

${ }^{*} p<0.10,{ }^{* *} p<0.05,{ }^{* * *} p<0.01$ 


\section{Gambar 2}

Hasil Evaluasi Model Struktural

Tabel 7

Pengaruh Langsung Iklim Organisasi Terhadap Kinerja Tanpa Variabel Stres Kerja

\begin{tabular}{|c|c|c|c|c|}
\hline Uji Hipotesis & $\begin{array}{c}\text { Prediksi } \\
\text { Tanda }\end{array}$ & $\begin{array}{c}\text { Koefisien } \\
\text { Jalur }\end{array}$ & $\begin{array}{c}\text { Standard } \\
\text { Error }\end{array}$ & $\begin{array}{c}\text { T } \\
\text { Statistics }\end{array}$ \\
\hline Iklim Organsiasi $\rightarrow$ Kinerja Karyawan & + & 0,473 & 0,116 & $4,066^{* * *}$ \\
\hline
\end{tabular}

Sumber : Data Olahan Smart PLS 2.0 M3 (2015)

* $\quad$ : Secara statistik signifikan pada level alpha $10 \%$

** : Secara statistik signifikan pada level alpha 5\%

*** : Secara statistik signifikan pada level alpha $1 \%$

Tabel 8

Hasil R Square

\begin{tabular}{|c|c|c||}
\hline Variabel & $\begin{array}{c}\mathbf{R}^{\mathbf{2}} \\
\text { (Stres Kerja Sebagai } \\
\text { Variabel Mediasi) }\end{array}$ & $\begin{array}{c}\mathbf{R}^{\mathbf{2}} \\
\text { (Tanpa Stres Kerja Sebagai } \\
\text { Variabel Mediasi) }\end{array}$ \\
\hline Kinerja Karyawan & 0,360016 & 0,223967 \\
\hline \hline
\end{tabular}

Sumber : Data Olahan Smart PLS 2.0 M3 (2015) 